\title{
HOUSING RESOURCES AND NEEDS IN LIGHT OF MODERN URBAN TRANSFORMATIONS: THE CASE OF POZNAN
}

\author{
Sławomir Palicki, PhD \\ Poznan University of Economics and Business \\ e-mail:Slawomir.Palicki@ue.poznan.pl
}

\begin{abstract}
Polish cities have been at the stage of a dynamic suburban development for over a decade (which has led to the phenomenon of urban sprawl beyond any control). The population of big urban areas, together with their agglomerations is continuously increasing; however, migration tendencies towards suburban areas are strong as well. In such a situation, the question arises regarding the possibilities and the methods of suppressing the outflow of people to the neighboring communities, and once again, making the city an attractive place to live. The attempt to explain such an issue requires research into both the housing infrastructure and its inhabitants.

Poznan has been severely affected by suburbanization. The diagnosis and assessment of Poznan housing resources and the preferences of its inhabitants are the starting point for taking further steps in making the housing conditions more attractive.

The article shows the initial results of widespread research regarding housing in the capital city of the Wielkopolska Province (comprising over 2,500 households). A similar study for the entire agglomeration (Poznan County) is due to be completed soon. It will allow for a comparative analysis and formulating recommendations regarding the conditions and the direction of changes on the real estate market which would increase the attractiveness of central cities suffering from suburbanization. In a wider context, the publication might be seen as an analysis of one of the elements of modern urban changes, such as either market driven, or free and spontaneous processes of urban sprawl, and conscious actions taken by local governments (together with developers) regarding the integrated urban revitalization policy.
\end{abstract}

Key words: housing market, housing resources, housing needs.

JEL Classification: $I 38, R 2, R 31$.

Citation: Palicki S., 2017, Housing Resources and Needs in Light of Modern Urban Transformations: the Case of Poznan, Real Estate Management and Valuation, vol. 25, no. 2, pp. 72-78.

DOI: 10.1515/remav-2017-0014

\section{Introduction}

Polish cities are now undergoing a stage of vigorous suburban development (which leads to the problem of the uncontrolled urban sprawl). The number of inhabitants of larger cities, estimated along with their agglomerations, is continuously increasing, but migration tendencies are still increasingly taking roots. Such a situation leads to the vital question regarding the possibilities of suppressing the outflow of people to neighboring communities and, once again, making the city an attractive place to live. An attempt to explain such an issue requires research into both the housing infrastructure and its inhabitants.

Poznan has been severely affected by suburbanization (BEIM, 2009). The diagnosis and assessment of the city's housing resources and the preferences of its inhabitants are the starting point for taking further steps to make housing conditions more attractive. The article presents the most important 
results regarding the housing area of the capital of Wielkopolska (the research comprises over 2,500 households). The aim of the article is to analyze and evaluate the attractiveness of housing resources and their surroundings in Poznan as seen by the users, together with the directions of possible changes suggested by the inhabitants. Another aim is to interpret the gap between the current state of housing resources in Poznan and the desired one. This might enrich the discussion regarding the changes in the real estate market which could limit the dynamics of suburbanization.

The article uses data gathered during research for the Poznan City Council (MATUSIAK et al. 2015).

\section{Literature review}

The modern processes of urban development point to the problem of suburbanization (SZYMAŃSKA, MATCZAK 2002; KOKOT, KIEPAS-KОКOT 2011; GNAT, BAS 2013). The overriding effect of the phenomenon is the dynamic development of suburban areas, which leads to urban sprawl, and to housing taking over farming areas and other so-called free spaces. Changes in the use of land, ground utilization, intensive housing in outside areas of the city (especially along exit roads), and the movement of people and companies towards such areas could be observed.

The most important features of suburbanization are: (PARYSEK 2010):

- the urbanization of suburbs,

- perypheralization of the city core,

- the development of external parts of a city,

- deconcentration and reconcentration of housing and function,

- inner-city enclaves,

- deindustrialization and reindustrialization,

- vanishing city limits,

- increasing social inequalities,

- more tension and conflicts.

Suburbanization is seen as a result of wealthier inhabitants migrating out of run-down central districts to the suburbs, which, thanks to their location, allow for convenient everyday commuting (MIESZKOWSKI, MiLls 1993). At the same time, suburbs usually offer better housing conditions as compared with the previous location (functionality and comfort) and improved quality of the surroundings (nature, quiet).

Suburbanization is related to the decrease of the population density of city centers along with the increase of density in suburbs, while the migration balance for the whole agglomeration is still positive. It must be underlined that suburbanization processes are generally seen as negative, especially regarding urban sprawl: the cost of developing and maintaining infrastructure increases, people without cars have a limited access to workplaces, external costs are generated, agricultural features of an area are destroyed, central cities are weakened by suburban counties taking over taxpayers - both individuals and companies (NEWBURN, BERCK 2011). However, people who have moved to the suburbs emphasize numerous advantages of such a change (MATUSIAK, PALICKI 2015).

A method of creating a counterweight to depopulation processes resulting from suburbanization is making the core of an agglomeration more attractive (BEAUREGARD 2005; BELL 2007; BERNACIAK 2015). The area of improving urban areas also includes revitalization. This is "...the process of leading degraded areas out of a crisis, in a complex manner, through integrated activities to the benefit of the local community, area and economy on the basis of the local revitalization project" (Revitalization Act, 2015). The city center is a common area for undergoing revitalization processes (FAULK 2006; FILION et al. 2004; PAZDER 2011). It is an area of a high quality space, creating phenomena such as socialization, tourist and business exchange, a major factor for city growth, and also determines the vitality and the development of a city (PALICKI 2009; PALICKI 2015; SNEPENGER et al. 1998; SOŁKIEWICZ-KOS 2014; TANAŚ 2015).

Housing is one of the elements of revitalization. The economic and demographic condition of Polish households determines both the functioning and the activity of the real estate market, especially at times of crisis (NYKIEL 2011; RACKA 2015; SIEMIŃSKA, RYMARZAK 2014). Looking for relatively cheap housing in the suburbs enhances the depopulation processes, weakening the central area. In view of such tendencies, the revitalization process is aimed at limiting, and next - inhibiting, the outflow of inhabitants. The preferences of potential buyers need to be recognized in order to make the concept of living within the center of an agglomeration attractive for them. Having done that, it is 
possible to design a housing policy the aims of which are integrated with the revitalization project and the development of a city. Integrity and synergy are the two most desired factors (MORANDI 2011).

\section{Data and methods}

The research was aimed at identifying the needs of Poznan citizens, seen as the difference between the current level of fulfilling their housing needs and the lowest acceptable level of a desired state. Respondents were asked to indicate a realistic state of desired housing, and not exaggerate. However, instead of the usual housing policy focused on people in need, the research focused on creating the image of an actual "target" home for the inhabitants of Poznan.

The research was carried out using the PAPI method - the respondents were visited at their homes by the interviewers. The random sample covered about $1 \%$ of all the houses in the city. A total of 2,573 adults were interviewed between $18^{\text {th }}$ August and $6^{\text {th }}$ October 2015.

The way of constructing the questions allowed for full comparability of results using multi-criteria evaluation of the current housing resources inhabited by the respondents, and their desired housing. The neighborhood and further surroundings were analyzed accordingly. The obtained characteristics of two states, i.e. the current one and the desired one, point to a gap which needs to be filled in order to make the center of Poznan competitive against the suburbs. The analysis was performed according to the income of households and the age of the respondents. However, it is possible to disaggregate results regarding future housing into six desired locations (the city center, downtown, housing estate, outskirts, suburbs and distant places). It was possible to point out the features which are expected to be at a high level among people preferring a particular type of location. The housing policy aimed at attracting a particular group should focus on such features. Due to limited possibilities of presentation, the article presents only the results for the entire focus group, without further division.

The choice of criteria characterizing houses and surroundings was made by brainstorming and an in-depth interview with different groups of housing beneficiaries and professionals connected with the field (architects, urban planners, members of the city council, developers). Ten criteria regarding the housing were ultimately chosen, i.e.: location, the appearance of the building, construction technology, the general technical condition of the building, the condition of the flat, the size of the flat (in relation to needs), the plan of the flat (functionality), the heating system (the relation of comfort to cost), the brightness, and the views. The surroundings of the building were characterized by 16 factors. Some of them regarded technical aspects (the state of pavements, curbs and driveways); others focused on the quality of the public space (playgrounds, recreational areas, kindergartens, schools, medical facilities), the area of local businesses and services, and transport features (public transport, parking spaces). Six features of the districts were analyzed as well, i.e.: easy access to school/work, proximity of a train/bus station, the prestige of a given place, the sentiment to an area (together with family relations), the opinion about the area, and planned changes (information about future investments). The Likert Scale was used to answer the questions (1-the worst, 5-the best).

\section{Empirical results}

Proceeding to the results of the research, it is worth presenting a few pieces of information showing the nature of the real estate market in Poznan. The average time of living in the current place is 19.4 years, while the current flat is the first privately-owned one for $52.1 \%$ of respondents. The median of the number of people in a flat is 3 , mostly married couples with children. The average floor area is 61 sq. $\mathrm{m}$ for flats and 145 sq. $\mathrm{m}$ for houses (MATUSIAK et al. 2015)

Tables 1-3 present the results of the research. The average evaluations of flats, surroundings and districts have been presented. The range of variability is $1-5$ ( 1 - the worst, 5 - the best). The obtained numbers were set against the values which were pointed out by the respondents as the lowest acceptable when buying a property meeting all their expectations. This makes it possible to indicate those criteria of space evaluation which are already at a sufficient level in Poznan, and to those which require some improvement.

The highest deficit level in regards to the desired level (0.65) is shown when it comes to heating seen as the comfort of heating in relation to its cost (Table 1). It is worth drawing attention to the fact that this feature was rated at the lowest level among all the criteria (3.68), with the view outside the window scoring only slightly better (3.76). The location and the brightness were rated best (4.39 and 4.29 respectively). The general outlook of inhabitants is positive. There is a slight shortfall when it comes to the general technical condition of buildings and the technology (a deficit of 0.42 and 0.39 
respectively). When it comes to the remaining features, there are no substantial differences between the current and desired state. This confirms the high level of satisfaction with housing resources in Poznan, since $85.2 \%$ of people are either happy or very happy with their homes.

Table 1

Evaluation of current housing resources and desired characteristics.

\begin{tabular}{lccc}
\hline \multicolumn{1}{c}{ Criteria/Type of flat } & Current & Future & $\begin{array}{c}\text { Direction of } \\
\text { changes } \\
\text { (desired - } \\
\text { current) }\end{array}$ \\
\hline $\begin{array}{l}\text { Location (the satisfaction from living in a given } \\
\text { area, district, center, suburbs etc.) }\end{array}$ & 4.39 & 4.15 & -0.24 \\
\hline Appearance of a building (the façade) & 3.94 & 3.88 & -0.06 \\
\hline Technology (quality, durability) & 3.83 & 4.33 & +0.39 \\
\hline $\begin{array}{l}\text { General technical condition (the façade, staircases, } \\
\text { basements, roof, drainpipes) }\end{array}$ & 3.95 & 4.37 & +0.42 \\
\hline $\begin{array}{l}\text { Technical condition of flat (installations, walls, } \\
\text { floors, windows) }\end{array}$ & 4.16 & 4.40 & +0.24 \\
\hline Size of flat (in relation to needs) & 4.19 & 4.16 & -0.03 \\
\hline Floor plan (functionality) & 4.18 & 4.15 & -0.03 \\
\hline Heating (comfort and cost) & 3.68 & 4.33 & +0.65 \\
\hline Brightness of rooms & 4.29 & 4.18 & -0.11 \\
\hline Attractiveness of views & 3.76 & 3.89 & +0.13 \\
\hline 10-criteria average & 4.04 & 4.18 & +0.14 \\
\hline
\end{tabular}

Source: Compiled by the author.

Table 2

Evaluation of current housing resources and characteristics of desired (future) ones.

\begin{tabular}{lccc}
\hline \multicolumn{1}{c}{ Criteria/Type of Flat } & Current & Future & $\begin{array}{c}\text { Direction of } \\
\text { changes } \\
\text { (desired - } \\
\text { current) }\end{array}$ \\
\hline Look of surrounding buildings, green areas, sandboxes etc. & 3.73 & 3.66 & -0.07 \\
\hline Accessibility of landscape architecture - benches, bins & 2.72 & 3.53 & +0.81 \\
\hline State of pavements and curbs, accessibility of driveways & 3.10 & 3.95 & +0.85 \\
\hline Noise (outside of a building) & 3.38 & 4.20 & +0.82 \\
\hline Proximity of green areas, parks & 3.90 & 4.10 & +0.20 \\
\hline Proximity of playgrounds for children & 3.48 & 3.08 & -0.40 \\
\hline Proximity of sport facilities & 3.51 & 3.38 & -0.13 \\
\hline Accessibility of trams & 3.11 & 3.83 & +0.72 \\
\hline Accessibility of buses & 4.05 & 4.04 & -0.01 \\
\hline Accessibility of parking places & 3.17 & 3.79 & +0.62 \\
\hline $\begin{array}{l}\text { Accessibility of local shops(greengrocer's, butcher', } \\
\text { chemist's) }\end{array}$ & 3.92 & 4.03 & +0.11 \\
\hline $\begin{array}{l}\text { Accessibility of service outlets (shoemaker, bank, post office, } \\
\text { restaurant) }\end{array}$ & 3.48 & 3.85 & +0.37 \\
\hline Proximity of kindergarten & 3.85 & 2.91 & -0.94 \\
\hline Proximity of school & 3.94 & 3.12 & -0.82 \\
\hline Accessibility of medical help (GP practice) & 3.80 & 4.16 & +0.36 \\
\hline Neighborhood safety & 3.88 & 4.54 & +0.66 \\
\hline 16-criteria average & 3.56 & 3.76 & +0.20 \\
\hline
\end{tabular}

Source: Compiled by the author. 
The surroundings of the respondents' buildings were evaluated as 0.48 lower than the features of flats. (Table 2). This may result from the fact that things which do not belong to the respondents are evaluated more harshly. The belonging - or the lack of it - might have legal, sociological or emotional characteristics. Areflection of such an attitude is the average evaluation of the desired state of the neighborhood (3.76) which is lower than the average value for flats (4.18). This is a manifestation of the fact that inhabitants have lower sensitivity and attention levels towards the neighborhood than towards their flats. The state of pavements, noise and the accessibility of landscape architecture show the highest levels of deficit (0.81-0.85), followed by trams, safety and parking space $(0.62-0.72)$. The main problems seen in the neighborhood regard the transport infrastructure, safety and aesthetics. The accessibility of landscape architecture was evaluated at the lowest level of all the considered features (2.72).

Table 3

Evaluation of the district where the current housing resources are located and the state of a district for desired (future) flat.

\begin{tabular}{|c|c|c|c|}
\hline Criteria/Type of flat & Current & Future & $\begin{array}{c}\text { Direction of } \\
\text { changes } \\
\text { (desired - } \\
\text { current) }\end{array}$ \\
\hline Easy access to school / work & 3.86 & 3.95 & +0.09 \\
\hline Accessibility of bus/train stations & 3.67 & 3.31 & -0.36 \\
\hline Prestige of a place & 3.69 & 3.31 & -0.38 \\
\hline $\begin{array}{l}\text { Sentiment for the area (together with family } \\
\text { relations), }\end{array}$ & 3.74 & 3.27 & -0.47 \\
\hline Opinions about a place (good/bad neighborhood) & 4.03 & 3.86 & -0.17 \\
\hline $\begin{array}{l}\text { Planned changes (information about future } \\
\text { investments). }\end{array}$ & 2.76 & 3.82 & +1.06 \\
\hline 6-criteria average & 3.63 & 3.59 & -0.04 \\
\hline
\end{tabular}

Source: Compiled by the author.

The criteria for the neighborhood are evaluated similarly to the surroundings of flats (3.63) (Table 3). However, it seems that for most of the analyzed features, their current state surpasses the expectations of inhabitants of given districts. The inhabitants of Poznan do not expect the improvement of access to work/school or train/bus station. However, the planned spatial changes and the access to information about investments in a given area are evaluated at a very low level (1.06 deficit). Attention has been drawn to the fact that Poznan inhabitants need to feel secure when it comes to the future of their surroundings. What is more, about $38 \%$ of inhabitants assess the process of informing about planned investments badly or very badly.

\section{Discussion and conclusions}

The manner of interpreting the range of the housing policy presented in the article goes beyond the usual limits. The scale of the research and its characteristics make it possible to generalize the conclusions for the entire population of Poznan. Thanks to this, it was possible to answer the question regarding the directions of housing development in Poznan for all of the social groups. The perception of attributes regarding housing resources was reflected in a cross-cutting manner. The needs, seen as expectations concerning the lowest acceptable levels of attractiveness of an area where people would potentially like to move were diagnosed as well. Setting the current image against the desired one allowed us to identify deficits in particular areas, and such areas where the situation is already balanced. Of course, the article presents average numbers which arise from the aggregation of all of the opinions among the respondents. A more in-depth analysis would allow for adjusting the offer of the new, integrated housing policy in agreement with developers and other groups of beneficiaries.

The general conclusion of the research is a high level of assessment regarding the current housing resources in Poznan. It is difficult to indicate a radically negative assessment of any feature of the property or its surroundings. The features which were assessed at the lowest level (the accessibility of landscape architecture and the planned changes) received scores at an average level of 2.7-2.8 on a 1-5 scale. The results point to a satisfactory level of housing resource quality in Poznan. Heating was the 
most commonly mentioned problem of current flats. Respondents highlighted that the cost of heating is too high in comparison with the obtained comfort. The technical condition of buildings and their technology left a lot to be desired as well. Any potential change of the last parameter would require changing the current place of living, as it is not possible to change the technology of a building (quality feature). The respondents evaluate their surroundings more harshly. It seems that these feature are perceived as "not mine", "somebody else's" or even "nobody's". Less immediate space is not influenced by them to such an extent as their flats. It is, in a way, a mechanism of rationalizing choices.

On the other hand, taking the positive evaluation of current flats into consideration, the high level of expectations regarding the potential flats ought to be pointed out. The inhabitants of Poznan are ambitious and demanding customers who suggest the need for improving the market offer. The average levels of deficits are not high (flat 0.14, surroundings 0.20 ), but the levels of marks in relation to the scale are around 4.

Only an in-depth analysis and interpretation of results for particular age and income groups, taking into consideration the location preferences of respondents, might make it possible to suggest concrete actions which could improve the housing situation shifting it in the desired direction. A multi-layered recognition of the desired values of the attributes of flats will help to understand which type of actions should be undertaken in order to improve the image of housing resources in a city, and to reduce the negative effects of suburbanization. At this point it can be recommended to:

- improve the technical condition of buildings,

- increase the number of landscape architecture elements in the housing areas,

- develop the tram network,

- increase the clarity of information regarding the investments to be undertaken in the space around housing areas.

The presented concept of research and the case study of Poznan might be an interesting area for introducing a new housing policy which would focus not only on social aspects, but also on integrating actions with conscious local development.

\section{References}

BEAuregard R.A., 2005, The Textures of Property Markets: Downtown Housing and Office Conversions in New York City, Urban Studies, 42(13), pp. 2431-2445

BEIM M., 2009, Modelowanie procesu suburbanizacji w aglomeracji poznańskiej (Modeling of the Suburbanization Process in the Poznan Agglomeration) [in Polish], Bogucki Wydawnictwo Naukowe

BELL D., 2007, The hospitable city: Social relations in commercial spaces, Progress in Human Geography, 31(1), pp. 7-22

BERNACIAK A., 2015, Wspótczesne przemiany centrów miast w świetle wybranych doświadczeń amerykańskich $i$ europejskich (Contemporary Changes of City Centres in the Light of Chosen American an European Experiences) [in Polish], Ruch Prawniczy, Ekonomiczny i Socjologiczny, 77(4), pp. 265-275

FAulK D., 2006, The Process and Practice of Downtown Revitalization, Review of Policy Research, 23(2), pp. 625-645

Filion P., Hoernig H., Bunting T., SAnds G., 2004, The Successful Few: Healthy Downtowns of Small Metropolitan Regions, Journal of the American Planning Association, 70(3), pp. 328-343

GNAT S., BAS M., 2013, Statistical Analysis of Chosen Aspects of Suburbanisation Process in Szczecin in 20062001, Real Estate Management and Valuation, Vol. 21, No. 3, pp. 71-80

KOKOT S., KIEPAS-KOKOT A., 2011, Efekty suburbanizacji aglomeracji szczecińskiej (Effects of Suburbanization of Szczecin Agglomeration) [in Polish], Wiadomości Statystyczne, No. 7-8, pp. 67-84

Matusiak M., PALICKi S., 2015, Potrzeby i preferencje mieszkaniowe poznaniaków - rekomendacje dla polityki mieszkaniowej (Housing Needs and Preferences of Poznan Citizens - Recomendations for the Housing Policy) [in Polish], maszynopis, Uniwersytet Ekonomiczny w Poznaniu, Poznań

MATUSIAK M., PALICKI S., STRĄCZKOWSKI Ł., 2015, Diagnoza potrzeb mieszkaniowych - Interpretacja badań ankietowych pt. Potrzeby $i$ preferencje mieszkaniowe poznaniaków (Housing Needs Diagnosis Interpretation of Opinion Poll Research entitled 'Housing Needs and Preferences of Poznan Citizens') [in Polish], maszynopis (typescript), Uniwersytet Ekonomiczny w Poznaniu, Poznan

Mieszkowski P., Mills E.S., 1993, The Causes of Metropolitan Suburbanization, The Journal of Economic Perspectives, Vol. 7, No. 3, pp. 135-147 
MORANDi C., 2011, Retail and Public Policies Supporting the Attractiveness of Italian Town Centres: The Case of the Milan Central Districts, Urban Design International, 16(3), pp. 227-237

NeWBURN D., BERCK P., 2011, Exurban development, Journal of Environmental Economics and Management, Vol. 62, pp. 323-336

NYKIEL L., 2011, Demograficzne uwarunkowania rozwoju mieszkalnictwa i rynku mieszkaniowego (Demographic Factors Influencing Housing and Housing Market Development) [in Polish], Studia i Materiały Towarzystwa Naukowego Nieruchomości (Journal of the Polish Real Estate Scientific Society), Vol. 19, No. 3, pp. 60-72

PALICKI S., 2009, Karta przestrzeni publicznej jako instrument kształtowania jakości przestrzeni miejskiej (The Public Space Charter as an Instrument Forming the Quality of Urban Space) [in Polish], Journal of the Polish Real Estate Scientific Society, Vol. 17, No. 3, pp. 103-113

PALICKI S., 2015, Multi-criteria Assessment of Public Space from the Social Perspective, Real Estate Management and Valuation, Vol. 23, No. 4, pp. 24-34

PARYSEK J.J., 2010, Problemy rozwoju przestrzennego powiatu poznańskiego. Między interesem indywidualnym a ogólnospołecznym (Problems of Spatial Development of Poznan Poviat. Betweem Individual and General Social Interest) [in Polish], Kronika powiatu poznańskiego, No. 1, 2010, Poznań

PAZDER D., 2011, The conception of cultural space revitalization as a way to increase downtown attractiveness. (A Case Study of Chosen Medium-Sized Towns in the Wielkopolska Region) [in Polish], Quaestiones Geographicae, Vol. 30, Issue 4, pp. 63-67

RĄCKA I., 2015, Czynniki atrakcyjności nieruchomości mieszkaniowych na obszarach podmiejskich Kalisza (Factors of Residential Real Estate Atractiveness in the Suburban Areas of Kalisz City) [in Polish], Problemy Rynku Nieruchomości (Problems of Real Estate Market), No. 2 (44), pp. 29-37

SIEMIŃSKA E., RYMARZAK M., 2014, Development Conditions of Polish Housing Market During Economic Crisis, Real Estate Management and Valuation, Vol. 22, Iss. 4, pp. 68-80

SNEPENGER D.J., REIMAN S., JOHNSON J., SNEPENGER M., 1998, Is Downtown Mainly for Tourists?, Journal of Travel Research, 36(3), pp. 5-12

SoŁKIEWICZ-KOS N., 2014, Kształtowanie przestrzeni publicznych na obszarach śródmiejskich na przykładzie miasta Czesstochowy (Forming of Public Spaces in the Downtown Areas on the Example of Czestochowa City) [in Polish], Zeszyty Naukowe Politechniki Częstochowskiej. Budownictwo, pp. 266-270

SZYMAŃSKA D., MATCZAK A., 2002, Urbanization in Poland: Tendencies and Transformation, European Urban and Regional Studies, Vol. 9, No 1, pp. 39-46

TANAŚ J., 2015, Użytkowanie nieruchomości lokalowych w strefie centralnej Poznania (Use of Premises in the Central Zone of Poznan) [in Polish], Ruch Prawniczy, Ekonomiczny i Socjologiczny, 77(1), pp. 369384

Ustawa z dnia 9 października 2015 r. o rewitalizacji (9th October Revitalization Act), http:/ / dziennikustaw.gov.pl/du/2015/1777 [06.12.2015] 